\title{
Quantifying Dissolved Silicate Fluxes across Heeia Shoreline in Hawaii Via Integrated Hydrological Modeling Approach
}

\author{
Kariem A. Ghazal ${ }^{1, *}$, Olkeba Tolessa Leta ${ }^{2}$, Aly I. El-Kadi ${ }^{2,3}$, Henrietta Dulai ${ }^{3}$ \\ ${ }^{1}$ Department of Soil Science and Water Resources, University of Kufa, Najaf, Iraq \\ ${ }^{2}$ Water Resources Research Center, University of Hawaii at Manoa, Honlulu, HI, USA \\ ${ }^{3}$ Department of Geology and Geophysics, University of Hawaii at Manoa, Honolulu, HI, USA
}

Copyright $\mathrm{C} 2018$ by authors, all rights reserved. Authors agree that this article remains permanently open access under the terms of the Creative Commons Attribution License 4.0 International License

\begin{abstract}
Dissolved silicate (DSi) is one of the essential elements of biogeochemical cycles in the coastal zones. It plays a vital role in the preservation of endemic diverse organism's structure like plankton groups. DSi estimation and distribution within coastal aquifer and its fluxes into the ocean has been getting great attention among researchers, managers, and policymakers especially who focus on the coastal environmental health. However, estimating DSi is very challenging due to the fact that the nutrient fluxes magnitude can vary spatially and temporally. In the Hawaiian coastlines, the main sources of DSi are the weathering products of basaltic rock and volcanic ashes, which mainly gets transported to the coast by groundwater flow. In this study, an integrated hydrological modeling approach is considered as a robust way to estimate DSi fluxes both at temporal and spatial scales. The integrated model consists of the SWAT, MODFLOW, and SEAWAT models. Hereto, we also estimated DSi fluxes under different scenarios, such as wetland restoration (LU), climate change (CL), and sea level rise (SLR). While the CL scenarios were run using the Representative Concentration Pathways (RCP) 4.5 and 8.5 scenarios for mid and late $21^{\text {st }}$ century, the SLR of 0.4 and 1.1 meter was assumed. The findings indicated that the average DSi flux under California grassland cover was about 48 moles per day that increased by $15 \%$ during the wet season and decreased by $16 \%$ during the dry season. The DSi fluxes were highly dependent on fresh submarine groundwater discharge (FSGD). The climate change had a more negative impact on DSi fluxes by $5 \%$ when compared to the 1.1 meter of SLR scenario. On the other hand, wetland restoration did not have a significant effect on DSi fluxes. The decrease in DSi fluxes under SLR and climate change had a positive effect on the accumulative storing of DSi within coastal wetland. Overall, the integrated hydrological modeling approach has drawn a
\end{abstract}

comprehensive picture of DSi fluxes and silicate behavior under various conditions within the Heeia coastal zone.

Keywords Dissolved Silicate, Heeia; Hawaii, Integrated Hydrological Modeling, Climate Change, Wetland Restoration

\section{Introduction}

The Heeia coastal zone in Hawaii is a typical example of groundwater dependent ecosystems due to the presence of boundary interface among the Island of Oahu's largest fishpond, the largest federally designated Wetland, and the Kaneohe Bay's greatest sheltered water body of coral reefs $[1,2]$. The prominent features of these ecosystems are considered attractive habitats for native species and the major sources of ecosystem services. For perspective, the Hawaiian Islands contain over 30 percent of the endangered species in the United States of America [3]. The freshwater flows play vital roles in preserving the native adjacent coastal ecosystems as it provides essential nutrients like DSi to the terrestrial and marine organisms.

Variable concentration distribution of DSi within Heeia shallow aquifer needs special attention and investigation. The high concentration of DSi and low salinity provide a clear signal of freshwater discharge across the coastline, especially in the Hawaiian Islands, where groundwater is the main source of DSi as the result of weathering basaltic bedrocks and volcanic ash $[4,5]$. Therefore, estimating the DSi fluxes across the Heeia coastal shoreline needs to sustain the environmental coastal health. The macronutrient DSi plays a vital role in sustaining coastal and oceanic ecosystems due to the marine organisms like phytoplankton's dependence on the availability of DSi [6]. Diatoms are one of the most abundant taxonomic groups 
of phytoplankton community, which consider the predominant contributors to global carbon fixation and bio-silicification processes in coastal ecosystem [7]. These diatom species and vascular plants are found to produce siliceous structures, such as internal or external skeletons $[8,9]$. Therefore, freshwater ecologists since the 1960's enhanced the knowledge of DSi fluxes in the environment [10]. Most studies of DSi distribution relied on direct water sample analyzsis $[11,12]$. Due to the complicated interactions at the interface of land and ocean, the estimation of DSi fluxes needs integrated modeling that considers the surface and ground water hydrology.

The integrated hydrological modeling approach used here as a tool to assess the spatial and temporal fluxes of DSi across the Heeia coastal shoreline. This study aims to assess the DSi fluxes as species transport across the Heeia coastal aquifer-ocean interface under different scenarios of dynamic variable land use and climate scenarios.

\section{Materials and Methods}

\subsection{Study Area}

The Heeia Watershed (Figure 1) is located on the windward side of the northeast coast of Oahu Island. Oahu is the third largest island of the Hawaiian archipelago. The watershed is located in the central part of the Koolau Poko District that is bounded to the north by the Kahaluu Watershed and to the south by the Kaneohe Watershed. The watershed bounded by the Heeia fishpond and Kaneohe Bay to the east and the crests of Koolau Mountains to the west. The Haiku and Iolekaa streams are the major perennial streams of Heeia Watershed $[13,14]$. The aquifer accumulates the fresh water in a large lens, which is maintained through direct recharge by rainfall and indirect recharge by seepage from high water level of dike-impounded groundwater [15]. Historically, the Heeia Watershed has been considered as one of the highest productive coastal areas in the Island of Oahu due to the taro and rice cultivation. In addition, the region is considered as an important economic resource due to the existence of the largest fishpond on Oahu at the Heeia Stream estuary. The Heeia Watershed is a precipitous, rugged, and narrow valley that transforms into a flat swamp region, which represents about half of the coastal plain [16].

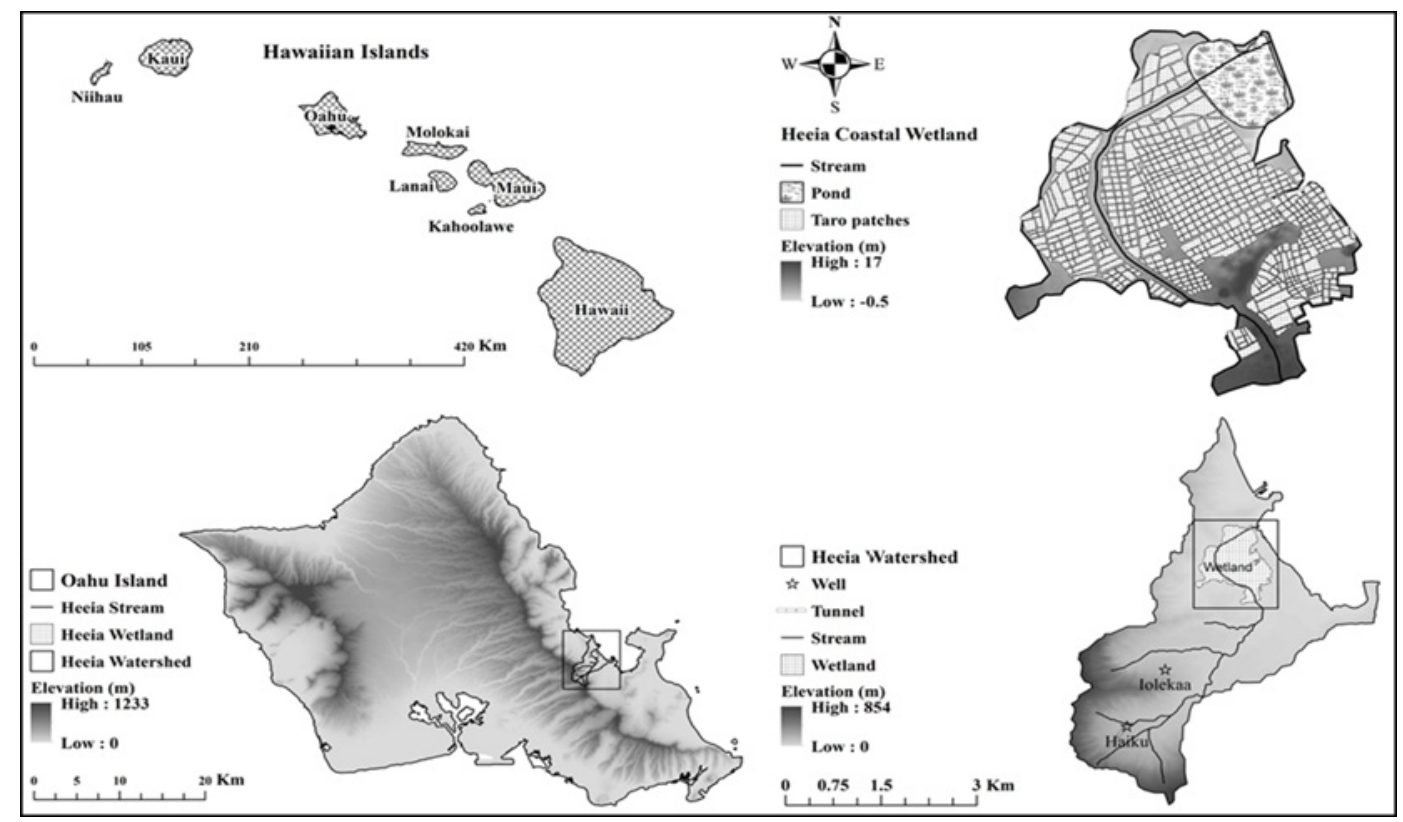

Figure 1. Geographic and topographic maps of the Heeia Coastal Wetland 


\subsection{Integrated Hydrological Modeling Description}

The integrated hydrological models include SWAT, MODFLOW, and SEAWAT models. The Soil and Water Assessment Tool (SWAT) model is a deterministic, semi-distributed, physically-based, and continuous watershed simulator operating on different time steps [17, 18]. The SWAT model has the ability to model ungauged or poorly gauged watersheds. The model was originally developed to predict the impact of watershed management on water quality and quantity at watershed scale [19]. SWAT is interfaced with a geographic information system (GIS) to integrate various spatial and hydro-meteorological data. The model uses a water balance equation that includes precipitation, surface runoff, actual evapotranspiration, interflow, percolation, return flow, and deep groundwater losses components [20, 21]. The output of groundwater recharge of SWAT is used as input for the transient-MODFLOW model to study the interaction between surface water and groundwater of the Heeia Wetlands.
The USGS MODFLOW model is a grid-based, fully-distributed, modular 3D groundwater flow model. The model numerically simulates saturated flow by solving the three-dimensional groundwater flow equation for porous media using a cell centered finite-difference approach [22]. MODFLOW is interfaced with Groundwater Modeling System (GMS), where the data input goes to the model while the GMS perform the model execution. The main steps of setting up MODFLOW model includes the planning, conceptualization, verification, calibration, validation, and predictive scenarios [23].

The SEAWAT model version 4 computer program is a coupled version of MODFLOW 2000 version 1.18.01 and MT3DMS version 5.2 designed to simulate three dimensional, variable density, saturated groundwater flow, and multi-species transport [24]. It has become a powerful tool to simulate the fluid density as a function of the solute concentration and hydraulic head gradient through the dispersion and advection processes [25].

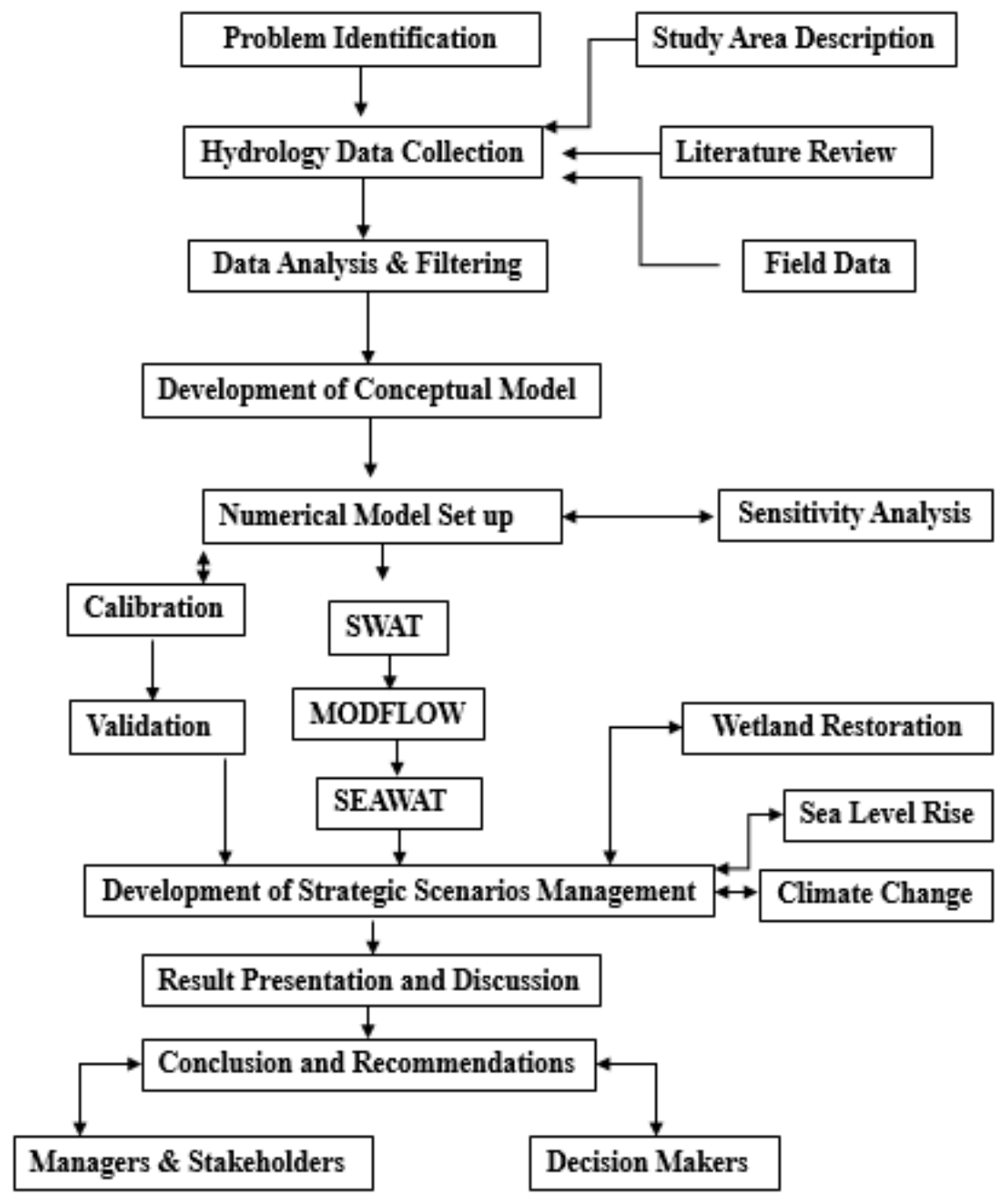

Figure 2. Flow chart for the research methodology 


\subsection{Research Methodology}

DSi fluxes were quantified by using the integrated hydrological modeling approach. The watershed model (SWAT), groundwater flow model (MODFLOW), and variable density dependent groundwater model (SEAWAT) were integrated to estimate the DSi fluxes across the Heeia coastal shoreline as a robust tool to assess the magnitude of DSi flux under different scenarios that included the LU, CL, and SLR. The modeling framework used in this study is shown in Figure 2.

\subsection{Data}

We collected groundwater samples in the wetland using piezometers from 0.5-2.0 $\mathrm{m}$ depth and surface water from the fishpond, stream, and irrigation ditches. Groundwater samples in the upper watershed were collected from wells operated by the Honolulu Board of Water Supply. The DSi $\left(\mathrm{Si}(\mathrm{OH})_{4}\right)$ in water samples was analyzed using well-established analytical methods at The Water Center at the University of Washington and the SOEST Laboratory for Analytical Biogeochemistry at the University of Hawaii (Table 1).

Table 1. The initial survey results of simulated species within the Heeia Watershed and coastal zone.

\begin{tabular}{|c|c|c|c|}
\hline \multirow{2}{*}{ Site name } & \multicolumn{2}{|c|}{ Coordinates } & Concentration [gm/l] \\
\cline { 2 - 4 } & $\mathrm{X}$ & $\mathrm{Y}$ & Dissolved silicate \\
\hline Heeia fishpond & 623426 & 2370733 & 0.005 \\
\hline Heeia fishpond & 623373 & 2371249 & 0.014 \\
\hline Heeia fishpond & 623480 & 2370708 & 0.002 \\
\hline Heeia fishpond & 623569 & 2370730 & 0.002 \\
\hline Heeia fishpond & 623812 & 2371074 & 0.002 \\
\hline Heeia fishpond & 623687 & 2371242 & 0.003 \\
\hline Heeia fishpond & 623501 & 2370430 & 0.023 \\
\hline Wetland weather station & 623108 & 2370386 & 0.021 \\
\hline Wetland second bridge & 623148 & 2370190 & 0.009 \\
\hline Wetland uphill road & 622369 & 2367583 & 0.012 \\
\hline Heeia stream & 621143 & 2368130 & 0.051 \\
\hline Kapuna_1 springs & 622067 & 2368130 & 0.063 \\
\hline Kapuna_2 springs & 622067 & 2369503 & 0.044 \\
\hline Baskerville surfacewater & 622782 & 2368571 & 0.058 \\
\hline Iolekaa well & 621757 & 2367581 & 0.049 \\
\hline Haiku well & 621145 & 2367581 & 0.035 \\
\hline Haiku tunnel & 621145 & & \\
\hline
\end{tabular}

We built-up the SWAT, MODFLOW, and SEAWAT models based on:

\section{Digital elevation maps:}

a A 10x10 m Digital Elevation Models (DEM) obtained from Department of Commerce (DOC), National Oceanic and Atmospheric Administration (NOAA), Center for Coastal Monitoring and Assessment (CCMA), and represents the upstream of the Heeia Watershed (Figure 1).

b A $3 \times 3$ m Coastal Lidar map obtained from NOAA Office for Coastal Management, and represents the coastal wetland area of the downstream of the Heeia Watershed (Figure 3). c A $4 \times 4 \mathrm{~m}$ the Heeia Bathymetry map provided by Pacific Islands Benthic Habitat Mapping Center, represents the Heeia shore (Figure 3).

2. Historical daily streamflow data of 1950 to 2014 downloaded from the Haiku station (USGS gauging station: 16275000).

3. A $2.4 \times 2.4 \mathrm{~m}$ land use map data downloaded from the NOAA Coastal Change Analysis Program (C-CAP) http://coast.noaa.gov/ccapftp.

4. A 1:24,000 scale soil map obtained from the Soil Survey Geographic (SSURGO) database as provided by the U.S. Department of Agriculture, Natural Resources Conservation Service (USDA-NRCS). 
5. A geologic map obtained from the U.S. Geological Survey (USGS) [26].

6. The aquifer parameters and geological structure estimated and extrapolated from the wells information within the study area, which obtained from previous studies in the same region [16, 27-30].

7. Historical sea level, air temperature, and ocean water temperature data obtained from the Department of Commerce (DOC), National Oceanic and Atmospheric Administration (NOAA), National Climatic Data Center (NCDC). The daily rainfall, solar radiation, wind speed, and maximum / minimum temperature data for the coastal zone obtained from the Hawaii Institute of Marine Biology (HIMB) at Coconut Island for the period of 2000 to 2014. Moreover, the daily rainfall data for the upland zone downloaded from the USGS station at the North Halawa Valley. Another source of daily rainfall and maximum/minimum temperature obtained from the National Climatic and Data Center (NCDC) of NOAA at Kaneohe 838.1 station

(http://www.ncdc.noaa.gov/cdo-web/datasets).

Available daily relative humidity data derived from the Western Region Climate Center (WRCC) at the Oahu Schofield East and Oahu Forest National Weather Research (NWR)

(http://www.raws.dri.edu/wraws/hiF.html). During this research, limited climatic data obtained for two years (2012-2013) from a weather station, which installed in the Heeia Wetland (WatchDog 2000 Series-Spectrum Technologies, Inc.). Rainfall Atlas of Hawaii $(250 \times 250 \mathrm{~m}$,

$\mathrm{http}: / /$ rainfall.geography.hawaii.edu/) used as reference of some climatic spatial patterns, which used for data rescaling.

\subsection{Sensitivity, Calibration and Validation}

Ghazal [31] developed SWAT model for the Heeia watershed. The author then ran sensitivity analysis, calibration, and validation of the model. This study used the calibrated and validated SWAT of Ghazal [31] for scenarios analysis. Thus, the reader is referred to Ghazal [31] for detailed results of sensitivity analysis, calibration and validation, including uncertainty and model performance evaluation.

\subsection{Integrated Modeling Approach}

In order to assess the density dependent groundwater flow and species transport across the Heeia coastal aquifer-ocean interface, the MODFLOW model was first developed for the Heeia coastal zone. The SWAT model estimated the recharge coverage of the study area, which was used as input to MODFLOW. SWAT estimated the recharge values under the Heeia's future wetland restoration, current and future climate change, and 1.1 meter of SLR. Then, the MODFLOW and SEAWAT models were run for each climate change (CL) and land use (LU) scenario's recharge values, including SLR. Finally, the SWAT estimated recharge values of CL and LU scenarios combined with SLR data were used as inputs to the MODFLOW and SEAWAT models. Additionally, MODFLOW 2000 was run for both steady and transient conditions. The SEAWAT model combined the MODFLOW and the solute transport MT3DMS model to simulate density dependent flow. In this study, the SEAWAT model was run to assess the DSi fluxes into the wetland and coastal ocean under different scenarios. Before the scenarios were run, the SWAT and MODFLOW models were calibrated and validated based on observed streamflow and groundwater levels, respectively. The SEAWAT model was calibrated by Ghazal [31] using sampled groundwater water levels at different locations (Figure 4). The SEAWAT model was validated to estimate the DSi fluxes across the Heeia coastal shoreline for different scenarios (Figure 5). 


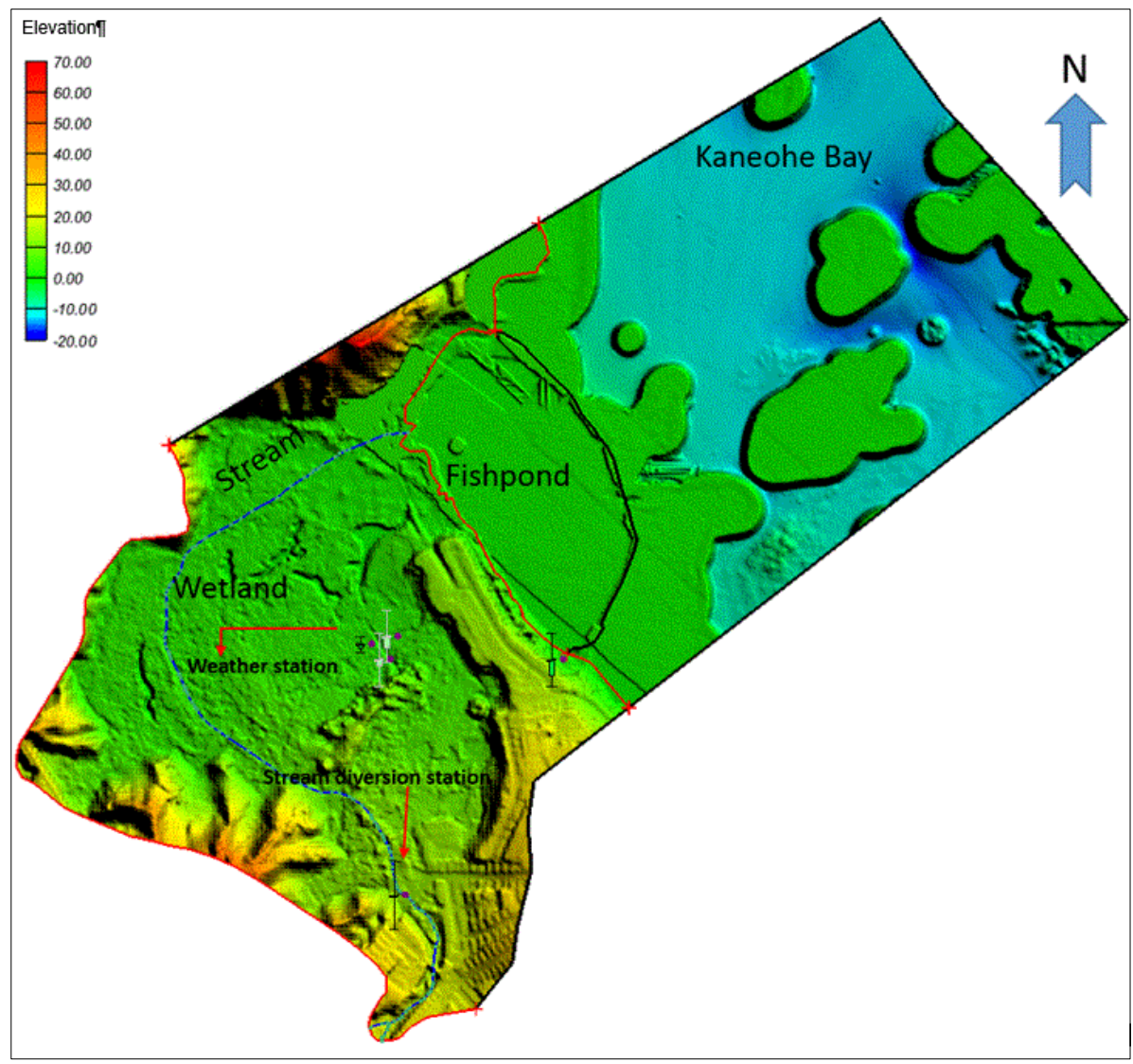

Figure 3. LiDAR digital map of the Heeia coastal zone

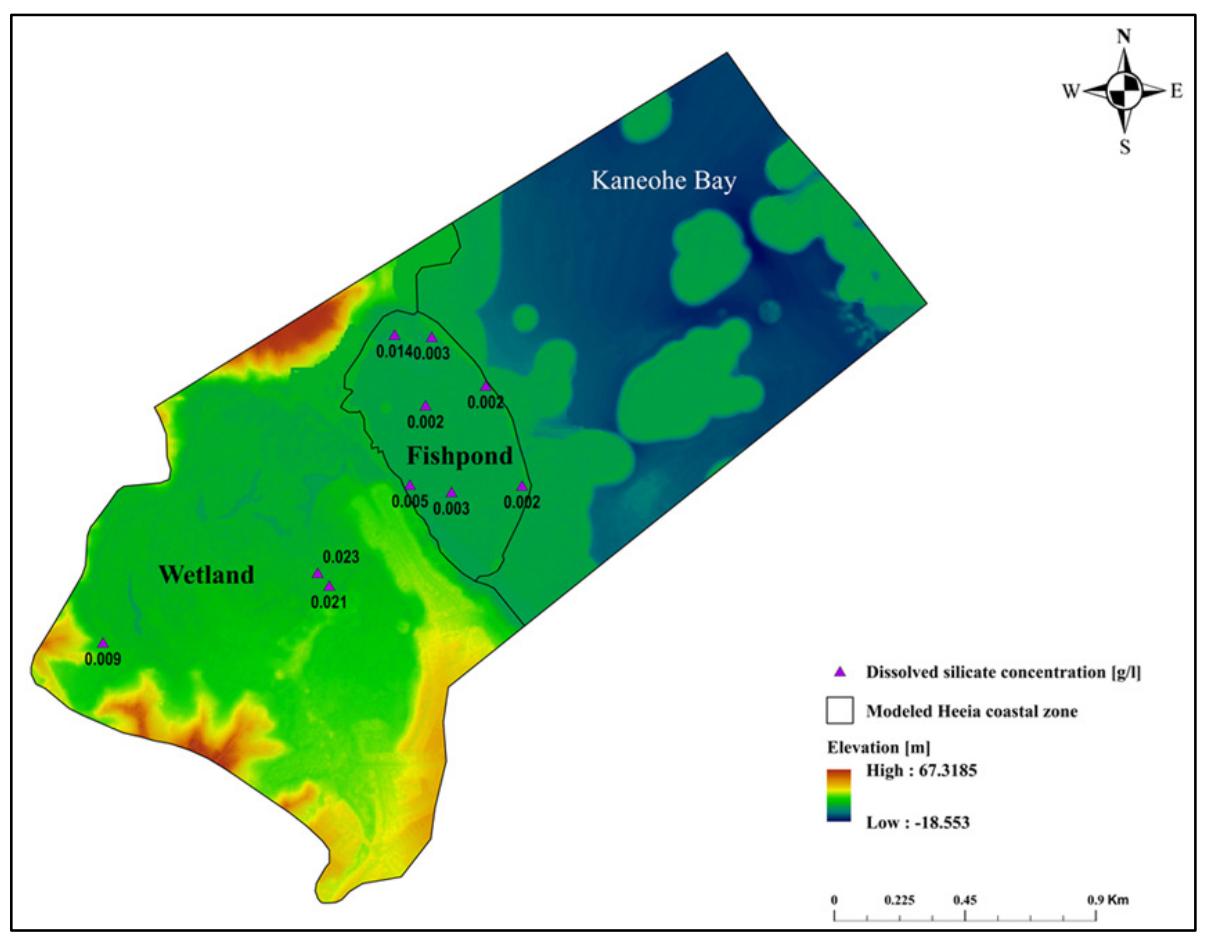

Figure 4. The effect of wetland accumulative storage on dissolved silicate distribution within the Heeia coastal zone. 


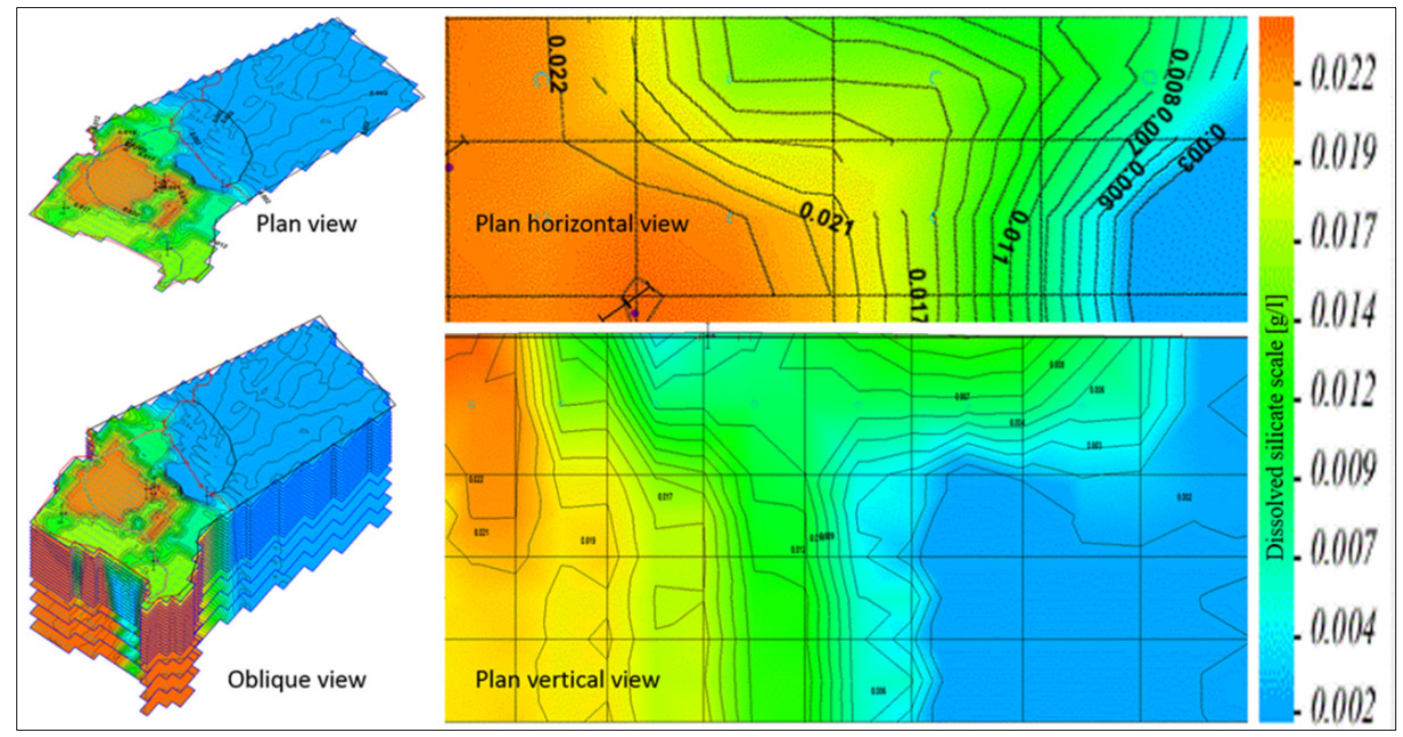

Figure 5. The horizontal and vertical sections of dissolved silicate distribution of the Heeia coastal zone by SEAWAT model

\subsection{Land Cover Change Scenario}

The Coastal Wetland Restoration plan (Figure 1) includes conversion of the california grass (Urochla mutica) to organic wetland taro (Colocasia esculenta) and the existing wetland mangrove forest to a pond as native habitat for aquatic species [32]. Based on the land use map data, the perennial california grassland mainly exists in the Coastal Wetland. It covers approximately $7 \%$ of the modeled area $\left(8.5 \mathrm{~km}^{2}\right)$. In addition, eight hectares of wetland mangrove forest ( $1 \%$ of the modeled area) is located around the Heeia stream estuary at the time of this study. The Estuarine Forested Wetland in the land use map of 2011 was treated as water code in the SWAT database during land cover change conversion, while the california grassland was converted to taro cultivation. As taro land use was not available in the current SWAT land uses database, taro parameters created based on the literature values and field measurements were added to the SWAT database.

\subsection{Climate Change and Sea Level Rise Scenarios}

This study used the statistically downscaled future rainfall changes over the Hawaiian Islands by Timm et al. [33] for the middle (2041-2070) and late $21^{\text {st }}$ century (2071-2100). Timm et al. [33] projected the wet season (November to April) and dry season (May to October) by using the RCP 4.5 and 8.5 scenarios of the International Panel on Climate Change (IPCC) Fifth Assessment Report (AR5) [34]. The rainfall anomalies data were separately available for wet and dry seasons as GIS layers in gridded format. The layers consist of eight GIS coverages for RCP 4.5 and 8.5 scenarios that represent four wet (mid and late century) and four dry (mid and late century) seasons. The rainfall anomalies per SWAT sub-basins were applied to the historical rainfall data of 2000 to 2014 . This analysis was completed by overlaying the statistically downscaled rainfall anomalies with the SWAT sub-basins. Details of this analysis is described in Leta et al. [35]. Finally, a sea level rise (SLR) of 0.4 and 1.1 meter was assumed based on the study by Rotzoll and Fletcher [36].

\section{Results and Discussion}

The statistical results analysis of daily streamflow simulation showed that the SWAT, MODFLOW, and SEAWAT models performances were within the generally acceptable criteria for model evaluation especially under scarcity of the data and daily time steps approach [31].

Estimating DSi is very challenging due to the fact that the nutrient fluxes magnitude can vary spatially and temporally, which in turn depends on the groundwater flow as the main source of DSi. In Hawaii, the main sources of DSi are the weathering products of basaltic rock and volcanic ashes. The SEAWAT model was constructed to estimate DSi fluxes under different scenarios of LU, CL, and SLR (Figure 5). The model calibration and validation were judged as satisfactory as reflected by high coefficient of determination value 0.99 and 0.91 , respectively. In addition, the observed and computed DSi showed good agreement (Figure 6). The results illustrated that the average DSi flux (baseline) was about 48 mole per day (Table 2) and increased by $15 \%$ during the wet season but decreased by $16 \%$ during the dry season due to the temporal variation of FSGD (Figure 7). An important note is that climate change has more negative effect on reducing the DSi fluxes than SLR, resulting in a more decrease in FSGD by $5 \%$ compare to the 1.1 meter SLR (Figure 8 ). The daily decreases in DSi fluxes across the coastal line relative to the baseline (grassland) were $0.3 \%, 2.6 \%, 8.5$, and $16.3 \%$ as a result of SLR by 0.4 meter and 1.1 meter, 
climate change (CL), and their combined effect of the latter two with taro land cover change (CLLU1.1SLR), respectively (Figure 8 ). On the other hand, the conversion of california grassland into taro showed an increase in the DSi magnitude by $1.7 \%$, which is due to decrease in the uptake of DSi by taro land cover compare to california grass. Therefore, the DSi values were very low within the fishpond due to its location at the mouth of Heeia stream and the accumulative storing of DSi within wetland.
The decrease in DSi fluxes under SLR and climate change had a positive effect on the accumulative storage of DSi within the coastal wetland (Figure 9). The reduction in DSi storage within the delineated wetland due to climate change impact would be $4 \%$ less than the impact of sea level rise $(1.1 \mathrm{~m})$. This is partly because of decrease in recharge and specified fluxes by $15 \%$ according to climate projection towards the end of the $21^{\text {st }}$ century and the effect of land cover change [9, 37].

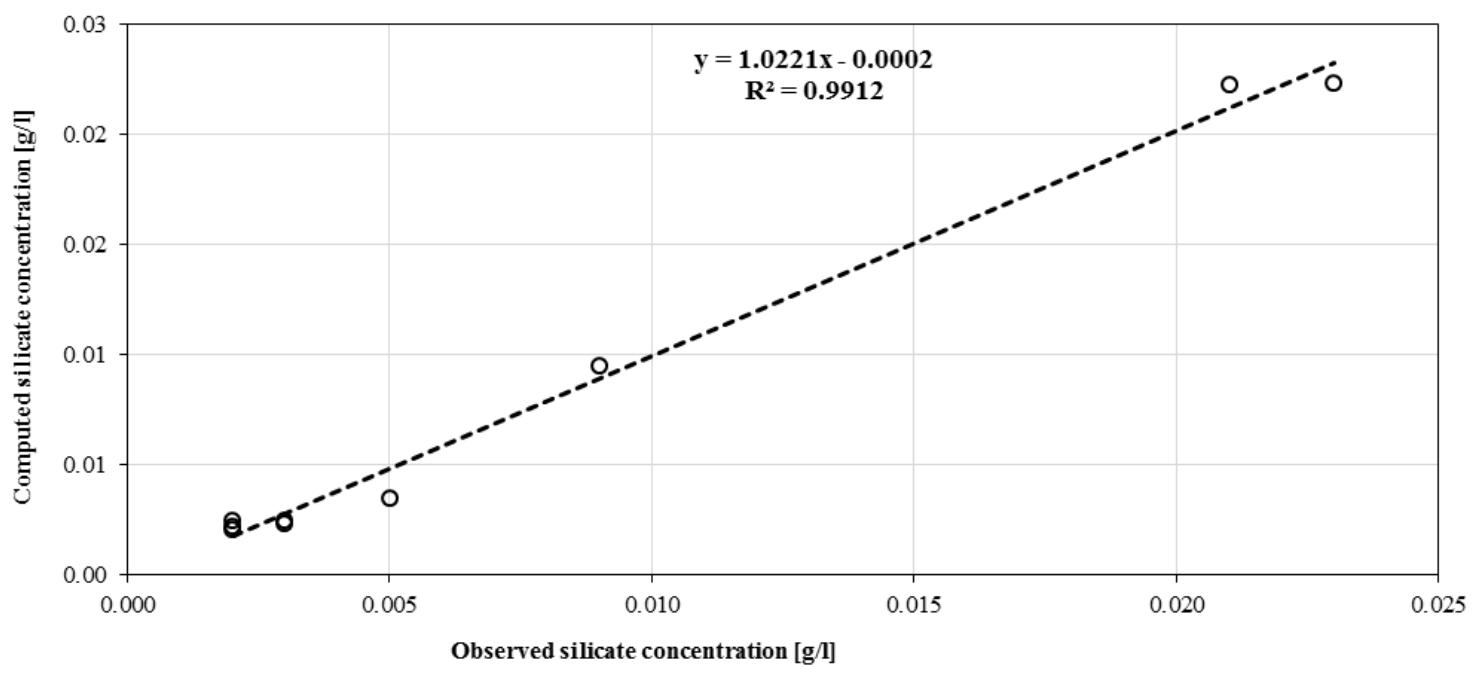

Figure 6. Regression plot for dissolved silicate concentration simulation for the calibrated SEAWAT model

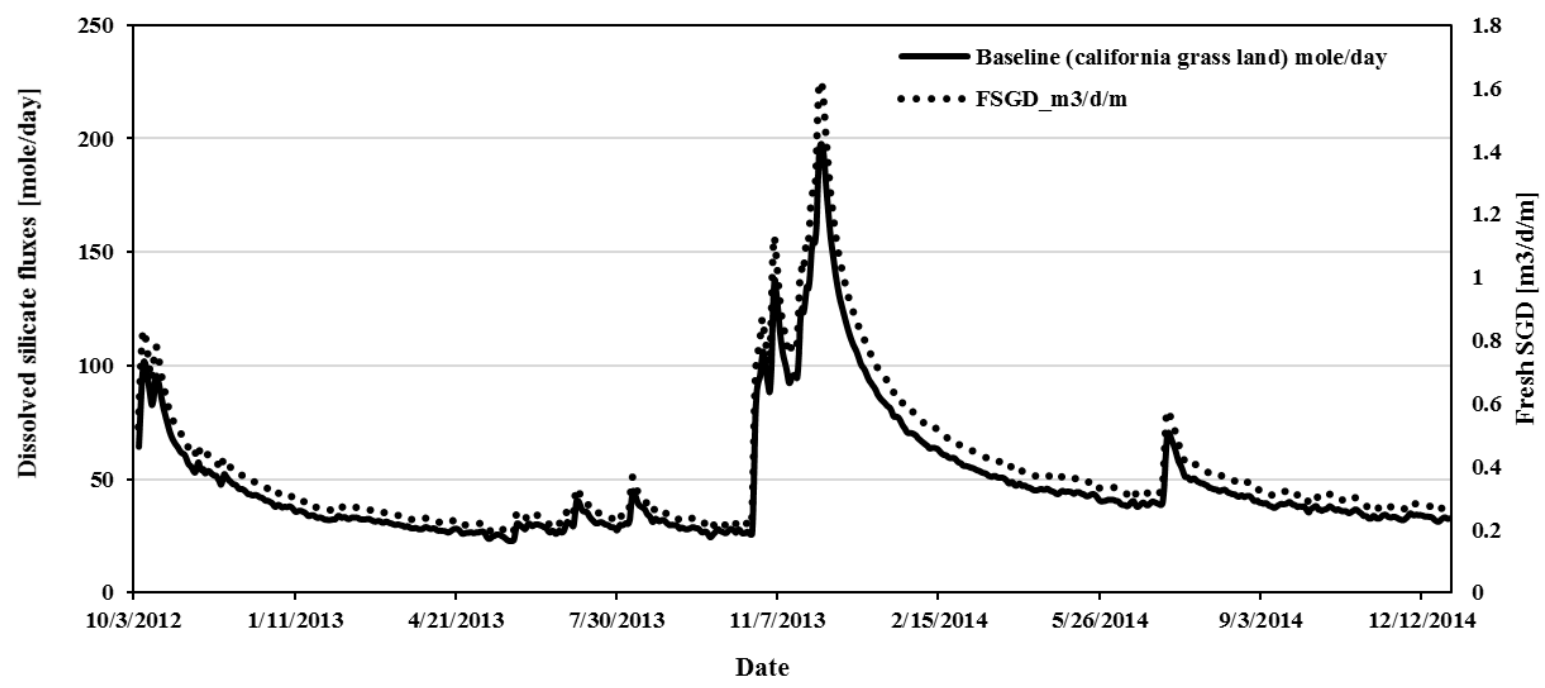

Figure 7. Daily estimated dissolved silicate fluxes across a meter of Heeia coastal shoreline. 


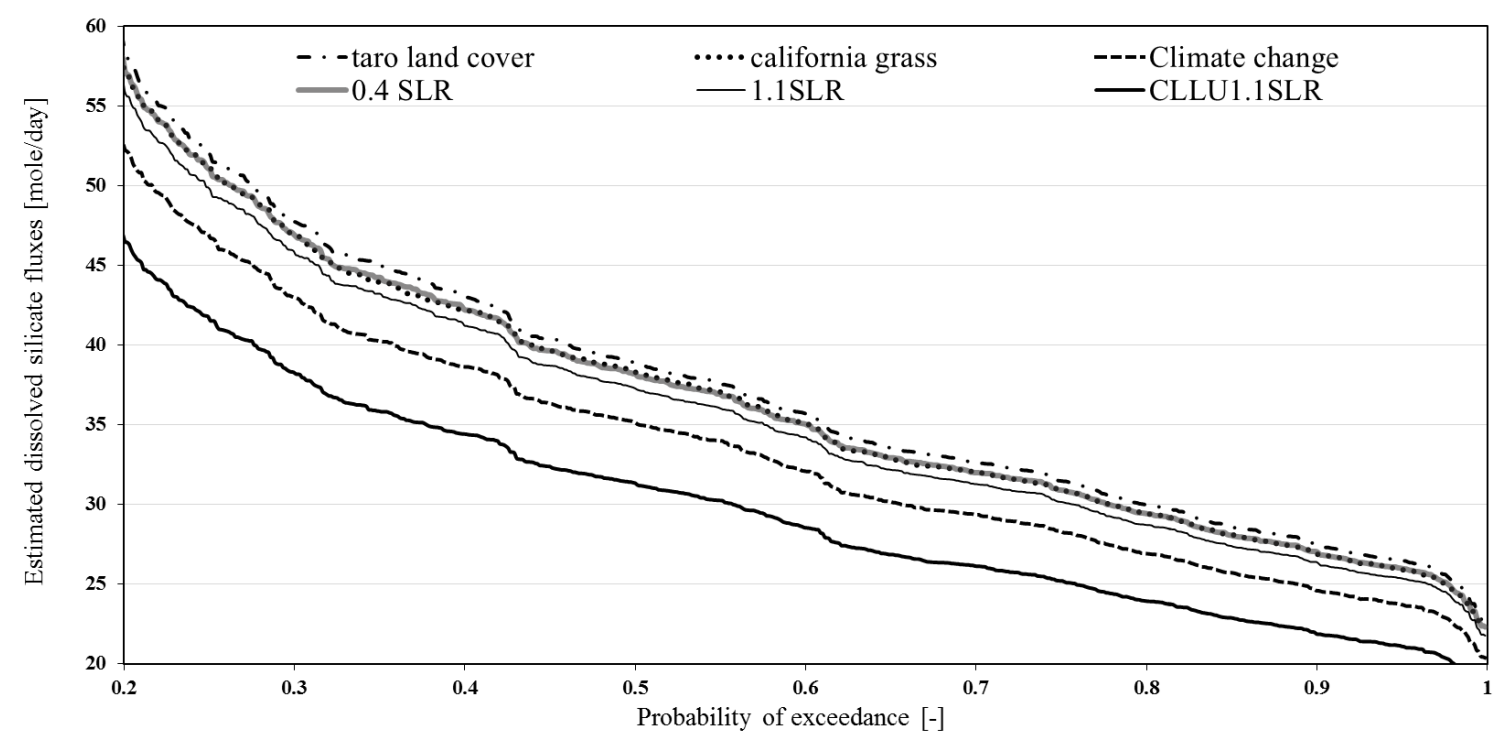

Figure 8. Daily dissolved silicate fluxes duration curve for different scenarios of land use change, climate change, and sea level rise.

Table 2. The percent change relative to the baseline and the statistical criteria of the daily dissolved silicate fluxes [mole/day] under different scenarios of land cover change, climate change, sea level rise, and combined effect.

\begin{tabular}{|l|c|c|c|c|c|}
\hline Scenario & Maximum & Minimum & Average & STD & $\begin{array}{c}\text { Relative } \\
\text { change (\%) }\end{array}$ \\
\hline Baseline (california grass land) & 194.2 & 22.3 & 47.6 & 27.7 & \\
\hline Taro land cover (LU) & 197.4 & 22.7 & 48.5 & 28.2 & 1.7 \\
\hline Sealevel rise (0.4 m) & 193.7 & 22.3 & 47.6 & 27.7 & -0.3 \\
\hline Sealevel rise (1.1 m) & 189.1 & 21.8 & 46.5 & 27.1 & -2.6 \\
\hline Climate change (CL) & 177.7 & 20.4 & 43.6 & 25.4 & -8.5 \\
\hline Combined effect (CL, LU, and 1.1 m SLR) & 158.3 & 18.1 & 38.8 & 22.6 & -16.3 \\
\hline
\end{tabular}

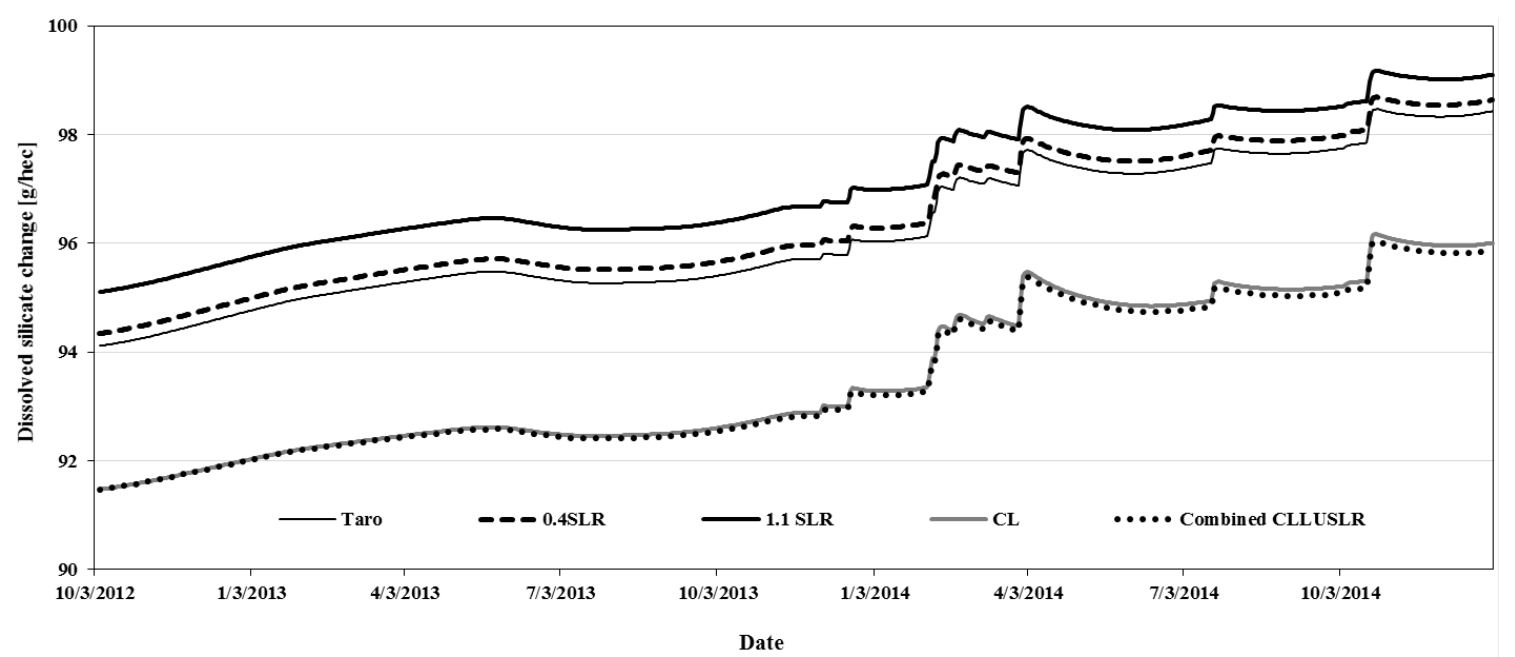

Figure 9. The daily changed dissolved silicate relative to the baseline (grassland) within taro patches under various scenarios.

\section{Conclusions}

This study integrated SWAT, MODFLOW, and SEAWAT models to simulate DSi fluxes across the Heeia coastal shoreline. The constructed models reasonably estimated the transient simulation of the DSi fluxes. It was found that, on average, DSi fluxes are expected to increase by $15 \%$ during the wet season while dry season is predicted to show a $16 \%$ decrease. As should be expected, DSi fluxes were a function of FSGD. Climate change more negatively affected DSi fluxes compared to SLR. Consequently, predicted DSi in FSGD will decrease by more than 5\% due to SLR by $1.1 \mathrm{~m}$. The LU did not show a significant effect on DSi fluxes. The decrease in DSi fluxes under SLR and 
CL might thus have a positive effect on the accumulative storing of DSi within coastal wetland. Despite data scarcity, the study has provided a comprehensive assessment of the DSi fluxes and silicate behavior under various conditions within the Heeia coastal zone. In addition, we can conclude that the DSi fluxes magnitude can vary spatially and temporally and this may have effects on DSi availability in the coastal environment.

\section{Acknowledgements}

The authors thank the Kakoo Oiwi community for facilitating the research. Kariem A. Ghazal acknowledges the Iraqi ministry of Higher Education and Scientific Research for sponsoring his study at the University of Hawaii at Manoa. This paper was partly funded by a grant from the Pacific Regional Integrated Sciences and Assessments (Pacific RISA), NOAA Climate Program Office grant NA10OAR4310216 and by the National Oceanic and Atmospheric Administration, Project R/IR-19, which is sponsored by the University of Hawaii Sea Grant College Program, SOEST, under Institutional Grant No. NA14OAR4170071 from NOAA Office of Sea Grant, Department of Commerce. The views expressed herein are those of the authors and never reflect the funding agencies. This is Sea Grant publication

UNIHI-SEAGRANT-JC-14-06, School of Ocean and Earth Science and Technology (SOEST) publication 10474, and a contributed paper WRRC-CP-2019-07 of Water Resources Research Center (WRRC), University of Hawaii at Manoa, Honolulu, Hawaii.

\section{REFERENCES}

[1] H. Dulaiova, A. Kleven, K. Ruttenberg, R. Briggs, and f. THOMAS, "Evaluation of submarine groundwater discharge as coastal nutrient source and its role in coastal groundwater quality and quantity." 2015.

[2] P. L. Jokiel, "Jokiel's illustrated scientific guide to Kaneohe Bay, Oahu," ed: Hawaiian Coral Reef Assessment and Monitoring Program, Hawaii Institute of Marine Biology, Kaneohe, Hawaii, 1991.

[3] W. Allen, "Restoring Hawaii's Dry Forests Research on Kona slope shows promise for native ecosystem recovery," Bioscience, vol. 50, no. 12, pp. 1037-1041, 2000.

[4] J. H. Street, K. L. Knee, E. E. Grossman, and A. Paytan, "Submarine groundwater discharge and nutrient addition to the coastal zone and coral reefs of leeward Hawai'i," Marine Chemistry, vol. 109, no. 3, pp. 355-376, 2008.

[5] F. N. Visher and J. F. Mink, Ground-water resources in southern Oahu, Hawaii. US Government Printing Office, 1964.

[6] V. Martin-Jézéquel, M. Hildebrand, and M. A. Brzezinski,
"Silicon metabolism in diatoms: implications for growth," Journal of phycology, vol. 36, no. 5, pp. 821-840, 2000.

[7] D. Werner, The biology of diatoms. Univ of California Press, 1977.

[8] T. L. Simpson and B. E. Volcani, Silicon and siliceous structures in biological systems. Springer Science \& Business Media, 2012.

[9] E. Struyf and D. J. Conley, "Silica: an essential nutrient in wetland biogeochemistry," Frontiers in Ecology and the Environment, vol. 7, no. 2, pp. 88-94, 2009.

[10] H. Dürr, M. Meybeck, J. Hartmann, G. Laruelle, and V. Roubeix, "Global spatial distribution of natural riverine silica inputs to the coastal zone," Biogeosciences, vol. 8, no. 3, pp. 597-620, 2011.

[11] J. Sospedra, L. F. H. Niencheski, S. Falco, C. F. Andrade, K. K. Attisano, and M. Rodilla, "Identifying the main sources of silicate in coastal waters of the Southern Gulf of Valencia (Western Mediterranean Sea)," Oceanologia, vol. 60, no. 1, pp. 52-64, 2018.

[12] A. Aminot and M. Chaussepied, Manuel des analyses chimiques en milieu marin (no. 551.464 AMI). 1983.

[13] Kailua Bay Advisory Council, "Ko'olaupoko Watershed Restoration Action Strategy Kailua Bay Advisory Council (KBAC)," Hawaii's Department of Health, Hawaii state2007.

[14] Kakoo Oiwi, " Heeia Wetlands Restoration," 2011.

[15] H. T. Stearns and K. N. Vaksvik, "Geology and ground-water resources of the island of Oahu, Hawaii," Hawaii Div. Hydrography, Bull, vol. 1, p. 536, 1935.

[16] S. K. Izuka, B. R. Hill, P. J. Shade, and G. W. Tribble, Geohydrology and possible transport routes of polychlorinated biphenyls in Haiku Valley, Oahu, Hawaii. US Department of the Interior, US Geological Survey, 1993.

[17] J. G. Arnold, R. Srinivasan, R. S. Muttiah, and J. R. Williams, "Large area hydrologic modeling and assessment part I: Model development1," ed: Wiley Online Library, 1998.

[18] P. W. Gassman, M. R. Reyes, C. H. Green, and J. G. Arnold, "The soil and water assessment tool: historical development, applications, and future research directions," 2007.

[19] J. Arnold, P. Allen, R. Muttiah, and G. Bernhardt, "Automated base flow separation and recession analysis techniques," Groundwater, vol. 33, no. 6, pp. 1010-1018, 1995.

[20] S. L. Neitsch, J. G. Arnold, J. R. Kiniry, and J. R. Williams, "Soil and water assessment tool theoretical documentation version 2009," Texas Water Resources Institute2011.

[21] M. Winchell, R. Srinivasan, M. Diluzio, and J. Arnold, "Arcswat Interface for Swat 2012: User Guider," Blackland Research Center, Texas AgriLife Research, 2013.

[22] A. Harbaugh and M. G. McDonald, "User's documentation for MODFLOW-2000, an update to the US Geological Survey modular finite-difference ground-water flow model," US Geological Survey, 2000. 
[23] B. Barnett et al., "Australian groundwater modelling guidelines," National Water Commission, Canberra, 2012.

[24] C. D. Langevin, D. T. Thorne Jr, A. M. Dausman, M. C. Sukop, and W. Guo, "SEAWAT Version 4: a computer program for simulation of multi-species solute and heat transport," Geological Survey (US)2328-7055, 2008.

[25] S. Guha, "Variable-density flow models of saltwater intrusion in coastal landforms in response to climate change induced sea level rise and a chapter on time-frequency analysis of ground penetrating radar signals," University of South Florida, 2010.

[26] D. R. Sherrod, J. M. Sinton, S. E. Watkins, and K. M. Brunt, "Geologic map of the State of Hawaii," Geological Survey (US)2331-1258, 2007.

[27] K. J. Takasaki, G. T. Hirashima, and E. R. Lubke, "Water resources of windward Oahu, Hawaii," 1969.

[28] P. T. Taniguchi, "Haiku Well at Haiku Valley, Koolaupoko, Oahu," Board of water supply City and County of Honolulu 1982.

[29] VTN Pacific, "Iolekaa Well at Haiku Valley, Koolaupoko, Oahu," City and County of Honolulu 1983.

[30] R. B. Whittier et al., "HAWAII SOURCE WATER ASSESSMENT PROGRAM REPORT," 2006, vol. I.
[31] K. A. Ghazal, "Integrated Hydrological Modeling for Water Resources Management of Heeia Coastal Wetland in Hawaii," University of Hawai'i at Manoa, 2017.

[32] Kakoo Oiwi, "Heeia Wetland Restoration Strategic Plan 2010 - 2015," 2010.

[33] O. E. Timm, T. W. Giambelluca, and H. F. Diaz, "Statistical downscaling of rainfall changes in Hawai ' $i$ based on the CMIP5 global model projections," Journal of Geophysical Research: Atmospheres, vol. 120, no. 1, pp. 92-112, 2015.

[34] I. W. SPM, "IPCC, 2014: Summary for policymakers," Climate change, 2014.

[35] O. T. Leta, A. I. El-Kadi, and H. Dulai, "Implications of Climate Change on Water Budgets and Reservoir Water Harvesting of Nuuanu Area Watersheds, Oahu, Hawaii," Journal of Water Resources Planning and Management, vol. 143, no. 11, p. 05017013, 2017.

[36] K. Rotzoll and C. H. Fletcher, "Assessment of groundwater inundation as a consequence of sea-level rise," Nature Climate Change, vol. 3, no. 5, pp. 477-481, 2013.

[37] K. Knee and A. Paytan, "4.08 submarine groundwater discharge: a source of nutrients, metals, and pollutants to the Coastal Ocean," Treatise Estuar. Coast. Sci, vol. 4, pp. 205-234, 2011. 